\title{
The North Central Association's I943 Survey of College and University Libraries
}

\author{
Mr. McEwen is librarian, Carleton Col- \\ lege, Northfield, Minn.
}

$\mathrm{T}_{\mathrm{C}}^{\mathrm{H}}$ HE NORTH CENTRAL ASSOCIATION of Colleges and Secondary Schools has just called on all its member institutions in the field of higher education for reports on their library resources and holdings. Its current practice is to request of member institutions a report on one of three aspects of their programs every two years. In 1943 libraries are being surveyed. In I 945 reports will be requested on college and university faculties, their training, teaching responsibilities, research, etc. In 1947 member institutions will report on their financial and budgetary situation and procedures.

A committee was appointed in June 1942 to prepare the forms to be used in this evaluation of the libraries of member institutions and of those institutions seeking accreditation by the association. The committee consisted of the chairman, Dean A. J. Brumbaugh, secretary of the Commission on Institutions of Higher Education, and four librarians to represent the four types of institutions in the association, as follows:

Group I institutions, offering two-year programs beyond high school graduation.

Group II institutions, offering only bachelor's degrees in a single unitary organization.
Group III institutions, offering master's degrees and/or professional degrees in a total of not more than three separately organized units.

Group IV institutions, offering doctor's degrees (Ph.D., Sc.D., Ed.D.), master's degrees, and/or professional degrees in a total of four or more separately organized units.

Each of the four librarians served also as chairman of a subcommittee of librarians and college presidents representing the designated type of institution. ${ }^{1}$

Librarians suffer at least as much from the burden of questionnaires and reports as other officers in higher education. Accrediting agencies and professional associations are entitled to the data necessary for their purposes. But it is felt increasingly that there should be closer coordination between the various organizations calling on librarians for such data, that it should be possible to limit requests for data to what can be supplied fairly readily, and that some reasonable limit should be imposed on the time required in providing the

\footnotetext{
${ }^{1}$ Members of these committees were as follows: Group I: Leon Carnovsky, University of Chicago chairman: President A Ándrews Grand Rapids Junior College; Wave L. Noggle, Virginia Junior. College.

Group II : Robert W McEwen, Carleton College, chairman; President V. F. Schwalm, Manchester College; President A. J. Burke, St. Ambrose College.

Group III: Julian S. Fowler, Oberlin College, chairman; President H. M. Gage, Lindenwood College; Clarence S. Paine, Beloit College.

Group IV: Errett W. McDiarmid Ùniversity of Illinois, chairman; Dean M. M. Willey, University of Minnesota; Charles H. Brown, Iowa State College.
} 
data. These considerations have been constantly in the mind of the committee responsible for the new survey schedules of the North Central Association. So far as possible, the information requested follows the forms adopted by the U.S. Office of Education and employed by the American Library Association. In passing, it may be said that several members of the committee, including the writer, expressed the opinion that the present U.S. Office of Education form is unnecessarily complicated and is in urgent need of revision and simplification. The committee hopes that its work marks a step toward such uniform report forms in higher education as are under consideration by the American Council on Education.

\section{Data Needed}

For the purposes of the North Central Association, in evaluating college and university libraries and their programs in member institutions and as a basis for consideration of requests for accreditation, it was agreed that some index to the following was needed:

I. The quality of the book collection with reference to the academic program of the institution concerned.

2. The adequacy of the list of periodicals currently received.

3. The expenditures of the library for salaries, books, periodicals, and binding and rebinding.

4. The use of the library collections.

To this end a revision of the checklist of books and the list of periodicals currently received was the primary task of the committee. Brief additional schedules call for the pertinent data on expenditures and use.

The most difficult task of the committee was the preparation of a new checklist of books. The North Central Association took an important forward step some few years ago in deciding to base its accreditation on the acknowledged aims and curricular objectives of each institution. The application of such a principle to the study of book collections might seem to imply procedures that would be quite impossible. The principle is quite right. Each college or university should hold the books needed for its own curricular program, which is the expression of its institutional aim. But how, then, could any list of books be prepared which might serve as a fair checklist of the holdings of all institutions and which might provide data for comparative and evaluative studies?

\section{Evaluating Book Collections}

Perfection is hardly to be expected in such matters. But the committee reached certain conclusions, based partially on previous practice, which we believe provide a dependable measure of book collections.

It was decided, first of all, to return to the principle of using reference titles only as the basis of the checklist. The assumption of the 1934 North Central checklist that there would be a high correlation between holdings in the reference collection and library book holdings in general was statistically established. Reference books have an additional value for such use. They are more likely to be free from any partisan bias than the general run of books in a library.

The 1939 revision of the North Central checklist has proved less satisfactory than the 1934 checklist. The revision in 1939 departed from the principle of using reference titles only and was based on the premise that great emphasis should be laid in such an evaluative schedule on current and recent acquisitions. The principal 
source of the 1939 checklist was the Shaw supplement of 1931-38. The sampling method employed in selecting the titles from the Shaw supplement resulted in the inclusion of books regarded by many librarians and college professors as quite unimportant. This criticism reflects an apparently widespread opinion that the Shaw supplement is less dependable as a "basic list" than its predecessor. The compilers of such lists must ignore the correlative criticism that certain important titles are omitted-that will always be true.

\section{Procedures Used}

It was felt that the checklist should include new as well as older titles. Reference titles in the original Shaw list, the Shaw supplement, the Mohrhardt list, and the Mudge-Winchell list, 1938-40, were clipped and mounted on cards. Duplications were deleted and certain series eliminated which would have involved improper balance in evaluating holdings. The cards were then examined at each of the four institutions represented by members of the committee. Titles whose importance was questioned were so marked. Members of the faculty as well as reference librarians were requested to assist in this evaluation. At a subsequent meeting of the committee titles whose importance had been questioned by more than one institution were examined again by the committee.

Judgments as to the importance of any specific reference book were involved in its original selection for any of the lists used as bases in the work of the committee. It was the judgment of the committee that further joint judgment by a number of subject specialists as well as librarians at four institutions would pro- vide a more dependable checklist than could be secured by the application of any sampling procedure to the total list of titles included in the basic lists.

All titles in the new checklist are arranged alphabetically to simplify checking in the libraries of member institutions. They are all keyed, however, with reference to the curricular department for which they are important. A college or university will be given credit for all titles on the list held by its library, but will not be penalized for the absence of specialized reference titles in fields in which the institution does not offer courses.

\section{Use of One Checklist}

The one checklist will be checked by institutions of all four types. There was discussion by the committee of the adequacy of any one list to cover the book collections in universities, junior colleges, teachers colleges, and liberal arts colleges. Should not a checklist for university libraries, for example, test holdings of special subject bibliographies, society serial publications, and specialized dictionaries and handbooks not needed in other types of institutions? The desirability of a more specialized approach such as this was admitted, but it was not deemed practicable within the limits of time and expense involved. In any case universities may reasonably be expected to hold a larger percentage of titles on such a list as the committee has developed and will be compared with other institutions of their own type in any evaluation.

In many cases the latest edition of handbooks, yearbooks, and similar reference tools is listed, and credit is given only for holding the latest edition. If separate checklists were prepared for the four types of institutions, credit might be 
allowed in institutions belonging to Group I, and perhaps Group II as well, for recent and usable editions other than the latest. Yet in such cases some edition must be specified, and the holding of the latest edition is felt to be very important for Group IV institutions and advisable in every case. A handbook of chemistry and physics published ten years ago may still contain useful and dependable tables and formulas, but colleges offering courses in these fields need the latest edition.

The revision of the checklist of periodicals currently received involved a study of the checklist in use by the association, based on the Lyle list of periodicals for a college library. Titles which have ceased publication were, of course, dropped from the list. In some cases, titles believed by members of the committee to be adequate substitutes for such withdrawn periodicals have been included. A few new titles have been added. Members of the faculty and library staffs at the four institutions represented by the committee participated in the decision in such cases. Libraries will no longer be asked to report on the binding of periodicals. The entire list is in one alphabet in order to reduce the time required to check it. Since some foreign periodicals not now being received in this country are on the list, libraries are asked to check whether they were received up to the time when delivery became impossible. Specialized subject field periodicals and a number of outstanding Catholic periodicals have been included in the one alphabetical periodical list. The holding of any such periodical will receive credit at any institution, but failure to receive it will not penalize an institution in which the periodical is not directly related to its program.

An additional schedule prepared by the committee will provide data needed by the association relative to library budgets and staff. This schedule constitutes a study of salaries, both academic and professional education, and experience of persons employed as librarian, assistant librarian, department head, or head of departmental or school libraries in member institutions. Total amounts spent for each of the past five years for salaries, books, periodicals, and binding and rebinding are called for.

\section{Measures of Use}

The final schedule deals with measures of use of library collections in member institutions. Its form represents the judgment of members of the committee that we do not have at the present time clear and dependable measures of the use made of our libraries. Institutions are asked to report on the measures employed by the library in checking on its own use by students and faculty and on the results available through such methods as to the use of the collections in the past year. Most institutions will probably report here the total number of two-week loans made to students and a similar figure for faculty loans, as called for by the U.S. Office of Education form. Such figures may represent the most adequate statistical report on use available. But their significance is so limited by a host of factors, such as the availability to students of other libraries, the adequacy of the college library's own collections, and the character of the curriculum and of the methods of teaching, that the committee felt it unwise to make such figures the basis for any comparative studies. The schedule as presented encourages individual institutions to report self-surveys which may be much more significant. 